\title{
Spaces of waiting: politics of precarious recognition in the occupied West Bank
}

\author{
Comesponding author: \\ Mikko Joronen \\ Space and Political Agency Research G roup (SPARG) \\ Faculty of Management \\ University of Tampere \\ Finland \\ mikk 0.joronen@ uta.fi
}

\begin{abstract}
This paper is an attempt to explicate a peculiar logic of government Israeli state apparatuses use to control the Palestinian population and colonize the West Bank; namely, the one of slowness, delay and waiting. To understand the operational logic of such governing, I suggest the conditions of recognizing Palestinian rights, their theatric performance by the Israeli state apparatuses, and the maintaining of precarity among Palestinians are the critical aspects to expand. By looking at the West Bank sites close to expanding Israeli settlements, I show how this mode of governing operates by recognizing the Palestinian right to claim justice, security and governance without actualization of these rights, therefore directing Palestinian resistance and sense of injustice to support the theatric functions of settler colonial state. Hence, theaters of recognition are created, the ones that ceremoniously keep administrative, legal and security processes functional, but through the slow processing, stalling and endless piling up of decisions, regulations, requirements and security exceptions do not alleviate the induced precarities.
\end{abstract}

\section{Introduction}

The words 'West Bank' and 'occupation' encompass strong spatial connotations: the (separation) wall, checkpoints, complex zonings one always feels uncanny uncertainty about, the archipelago of enclaves, the shrinking map of West Bank. It is hardly a surprise that raising the idea of 'waiting' in the context of occupied West Bank also travels quite quickly along similar pathways: queues at checkpoints, Palestinian workers corralled into corridors like cattle, daily detours caused by roadblocks, moving checkpoints, traffic jams - all kinds of movements controlled by all kinds of visible borders. Yet, waiting is never merely about obstructed movement entwined around spatial obstacles and border conditions of different kinds; it is also temporal, a delay, postponement, or a restraint, preventing things to come about. Contributions posing the question of government in relation to waiting have been quite keen to reckon this connection between space, time and mobility, as spatial obstacles of movement - walls, blocks, checkpoints, borders - intrinsically produce temporal delays and waiting - the queues, the lines of cars, and the livestock alleys of humiliated Palestinian bodies (see Bissell, 2007; Kotef, 2015; Wick, 2011; Tawil-Souri, 2011). The power of waiting - the force hidden within the ability to 'steal time' (Peteet, 2008) - however, has been under less scrutiny, perhaps as it often remains quite self-evident that waiting and obstacles of movement take away the time one possesses as his/ her own (See, Secor, 2007: 39-41).

In this paper, I turn this problematique around by asking how and through what techniques and configurations waiting itself can operate as a way of governing the occupied spaces and bodies. In particular, I show how it is the delay itself, when used as a settler colonial strategy of government, which produces control through what I call the precarious 'spaces of waiting'. With 'spaces of waiting' I do not refer to a difference in experiencing prolonged and 'chronic waiting' (Jeffrey, 2008), but rather to a settler colonial modality and techniques of governing occupied spaces and populations. In fact, if we look at the techniques the state of Israel uses to confiscate land, demolish homes, and plan land use in the West Bank, the highly precarious Area $\mathrm{C}$ in particular, this configuration of government emerges as a steady part of how the settler colonial rule is maintained and expanded in practice. Such government, I argue, operates through the performances of state apparatuses, which constantly delay and postpone actions that would diminish the precarious conditions among 
Palestinian population, especially among those suffering the corollaries of the close proximity of Israeli settlements. These spaces of suspension operate as sites of administrative and juridico-political performances, which govern by stalling the implementation of Palestinian rights, so creating spaces that theatrically keep the state apparatuses operative in a manner seemingly peculiar to liberal states (cf. Khalili, 2013; Ram, 2013, 2015; Shalhoub-Kevorkian, 2015; Yiftachel, 1998). Here, the ones governed are not subsumed under the disciplinary and surveillance techniques (Weizman, 2007), nor turned into passive targets of oppressive powers (Parsons and Salter, 2008). Rather, their practices of resistance are recognized and directed to maintain the theaters of recognition, which by preserving the precarious position of the ones governed, normalize, maintain and strengthen the discriminatory structures of the settler colonial rule.

To explicate the techniques of this way of governing, I start the paper by closely looking at four instances (in two sites), where the legal and political 'right to claim rights' is recognized, but its actualization delayed, prolonged or denied. Although in many cases different Israeli apparatuses military, legal and administrative - operate by supporting one another, in other instances the decision of one body (Israeli High Court of Justice, for instance) is prevented to actualize by the acts of other governing bodies (by Israeli D efense Forces (ID F) or Israeli Civil Administration (ICA), for instance). After looking at several techniques and events prolonging the already induced precarities of the occupation, I move on to discuss what I argue are the conditions intrinsic for their functioning as spaces of waiting: the configuration of the conditions of recognizability, the theatric performance of rights, and the inducing of precarity. Although there already exist relatively established discussions on the politics of precarity, recognition and performativity in the geographical literature, these discussions more often focus on the ways in which the marginalized, discriminated and precarious claim their rights via recognition, performative politics and/ or the alleviation of precarity (e.g. Harker, 2012; Staeheli, 2008; van Wichelen, 2015; Vasudevan, 2014). By discussing the recent works of Judith Butler (in part three) and Mitch Rose (in part four), my aim is to show how these three conditions of waiting can be, and have been, used as means to govern and colonize land. In particular, I want to show how in the space of waiting an ambiguous site for a juridico-political performance is unfolded as a key element of settler colonial strategy, where the legal and political 'right to claim rights' is recognized without reduction of the precarity of the ones governed. The paper concludes by arguing that without alleviation of precarity and renunciation of settler colonialism, recognitions of these kinds merely end up reconstituting the subsuming settler colonial power relations.

\section{Waiting the right that never comes: permits, procedures and legalities}

The argument put forward in this paper grows from the observations and remarks I have made during several fieldwork periods focusing on the manifold ways in which Israel governs and controls the O ccupied West Bank. ${ }^{1}$ Yet, more than anything, it grows from a sense of discontent and incongruity in several efforts to enforce Western theories of government, whether consisting of the 'politics of exception' or thanatopolitical strategies, all seemingly pertinent to complement a group of events unfolding in the stories told by West Bank Palestinians. These stories - as told by the locals and/ or written down by me as ethnographic descriptions - seemed to resist the already known denouement the existing explanatory frameworks of governance were proposing, thus always leaving a sense of inexhaustibility and unarticulated residue floating in the air (cf. Griffiths, 2017). Herein, my aim is to start from these residues, asking what these unfit stories can tell us about the operations of settler colonial regime, its ways of governing the occupied in particular. I put together several such stories, forming them into a set of descriptions, which I further use to pave the way for a discussion of a mode of government they unfold: namely, the one based on precarious waiting of rights in the theaters of recognition. Rather than predefining a theoretical framework - an approach particularly

\footnotetext{
${ }^{1}$ Fieldworks were conducted between 2013 and 2016, and consisted of several methods ranking from ethnographic descriptions and policy document analysis to observations, interviews, research diaries and other relevant materials collected from the online sources, key actors (state bodies, $\mathrm{NGO}$ 's, research institutes, UN), and from the sites under study.
} 
problematic due to the dangers of ontological 'closures', 'path-dependencies' and 'colonial ways of being' (See Blaser, 2014; Joronen and Häkli, 2016; Sundberg, 2014) - the conceptualization of governmental logic(s) stems from the events these stories gradually unfold. Such acknowledgement of the 'stories of others' is not merely an ethical responsibility of the researcher, but indebtedness that brings our own vulnerability to the fore - that is, our fundamental reliance on the stories others tell (Rose, 2016: 12).

My first set of stories comes from the West Bank village of Tuqu', located approximately eight kilometers southeast of Bethlehem. Tuqu' (with four village centers) is one of the many Palestinian municipalities that since the $\mathrm{O}$ slo Accords in the mid 1990s has been under the joint governance of Israeli and Palestinian authorities (i.e. classified as Area B). However, as is often the case in the West Bank, the agricultural fields and pastoral lands surrounding the village center remain in the severely vulnerable 'Area C', under the full Israeli administrative and security control (Area C consists of c. $87 \%$ of the West Bank territory; OCHA, 2014a). In fact, only 1.5\% of Tuqu' is designated Area B, while $74.1 \%$ is Area $\mathrm{C}$, the rest consisting of a nature reserve (ARIJ, 2010). The zoning itself was supposed to offer a temporary solution until Israel's withdrawal from the West Bank, originally scheduled for May 1999. Since then, however, Israel has used the grasp it gained from the mostly rural 'Area C' to offensively expand its settlement enterprise. This has also been the case in Tuqu', which today is surrounded by four settlement complexes with several outposts, some formed only recently (B'Tselem, 2014; Stahl, 2015).

It is May 2016, and we (me and my research assistant) have arrived in Tuqu' to interview the deputy mayor about the violence related to the close proximity and expansion of surrounding settlements. The taxi driver from Bethlehem is unsure about the exact location of our destination, but after few U-turns, narrow alleys and phone calls, we eventually arrive at our host's house. The mayor welcomes us, and gestures us into his living room to escape the heat. After formal compliments, a few surprise local guests quickly dropping by, and cups of sugary mint tea, I finally have a chance to ask about the problems Tuqu' has faced since my last visit in summer 2015. The mayor is consistent in his explanations of familiar developments - the continuing lack of opportunities to improve Palestinian living conditions, the constant denial of building permits, shrinking land area epiphenomenal to Israeli land confiscations, the destruction of olive trees, attacks accomplished by settlers, the illegal construction of settlement outposts, and the always-topical water shortage issues.

To show the current state of affairs, our host offers to take us to see the venues of former events, some of which I previously visited in 2015. We jump into the municipality jeep and head towards the agricultural road leading to the agricultural lands in the east. After some minutes, our guide slows down, as the road suddenly becomes uneven. I recall my last visit, when our guide stopped the car at this exact place in the front end of the agricultural road. The spatial patterns of settlements and outposts of Tekoa are still visibly present on our left side (Weizman, 2007), but the bulldozers parked on the right side of the road are now gone. The missing bulldozers remind me about the story one of the interviewees related in 2015. Accordingly, the municipality of Tuqu' had tried several times to appeal for a building permit for the distinctly poor-conditioned road we are now standing on. After years of waiting, the repair work, which had already gained funding from the EU via Palestinian 'Union of Agricultural Work Committees' (UNWC, 2014) and verbal permission from the Israeli authorities, could not be further delayed - especially as the road was the only one leading from the town center to the eastem agricultural areas, hence affecting the daily lives of several villagers. Only a few days after the construction was started, a group of settlers, secured by the Israeli military, came to suspend the work under the claim that it lacked the proper building permit; the soldiers also threatened the private constructor from Hebron, now gone with his machines, with the equipment distrain. A week later, the municipality received an official demolition order from the ICA (Israeli Civil Administration, a military body dealing with the civil population under occupation), to destroy the already repaired part of the road (See also POICA, 2015; UAWC, 2016). Curiously, the ICA responded to the situation almost immediately, but also ordered the municipality to return the road 
to a poorer condition than it was before the development project. The settlement council even sent a complaint to the EU about funding the Palestinian road' our guide bridles when I ask about the year-old events, and continues: 'It is an old road, it is not like we are building a new one'.

Another municipality worker I interview the next day sarcastically laughs while showing me the original ICA demolition order (no. 181 239). 'Settlers even tried to sue the municipality', he says, 'because we want to repair an agricultural road!' Although the events seem to afford an example par ex cellenoe of the strategic role frontier settlements have, not only in expanding the territory of Israel but also in informal policing of Palestinians from the perched positions of hilltop settlements, all the interviewees seemed to be more worried about knowing what the next step(s) will bring about. Accordingly, the municipality is preparing a complaint about the demolition order for the Israeli courts, which they know to be an expensive and long process. Meanwhile, the bulldozers stay immobile and the precarious status quo remains.

On our way forward, the deputy mayor points out several sites of newly constructed wells. All 12 of them - some old wells, others built by farmers and shepherds working far outside the town water infrastructure - are now under a demolition order by the ICA. The formula keeps repeating: Palestinians own the lands (in this case privately), have original registration documents, apply for building permits, wait for a considerably long time, and when they finally repair or construct the wells, in this case with financial support from the EU, they receive demolition orders. 'Farmers are not fully funded by the EU', the deputy mayor adds, and continues: 'a water well, for instance, costs around 3000 euros, of which the farmer pays $25 \%$. Demolition orders are not only about destroying the wells, but farmers lose their money'. Curiously, Tuqu' does have rich groundwater resources, but all water related development outside the regulated quotas purchased from the Israeli national water company are, almost without exception, denied by the Israeli authorities. According to the Palestinian Ministry of Planning and Administrative Development (2015: 11), West Bank Palestinians use an average of 76.4 liters of water per capita per day, although in Tuqu' the rate has been considerably lower - 45 liters per capita per day in the latest survey, with the actual consumption being as low as 27.5 liters due to water loses (ARIJ, 2010:14). This is not the case in settlements equipped with highquality water infrastructure capable of providing uninterrupted water supply enough to sustain swimming pools, agriculture, industry etc. with a daily average consumption of 240 liters of water per capita (Ewash, 2016). ${ }^{2}$

After passing through the olive fields, we arrive at a small hilltop, where a herd of goats crossing the road stops us, at precisely the right time it seems, as we have arrived at our destination of one of the oldest wells of Tuqu' still in use. After exchanging a few words with an old shepherd who had arrived to water his stock, we walk about twenty meters to look at a new road, which settlers, according to the shepherd, had only recently started to construct. Another hilltop, surrounded by a colony of houses, appears to be about half a kilometer in front of us. Its outermost buildings reach almost to the edge of Palestinian olive fields in the valley, which is not surprising, as the outpost we are looking at, the Tekoa $\mathrm{D}$, is one of the many unauthorized colonies that reside partly outside Israel's own (illicit) settlement master plan (ARIJ, 2015; Levinson, 2015). In fact, Tekoa D was unilaterally established in 2001 by the families of two settler teenagers found dead in a cave a few hundred meters away from the current outpost location, and hence serves as a textbook example of the vigilantism settlers use to confiscate land without consequences.

Another interviewee, a former official of Tuqu' who during the turn of the millennium worked for the municipality, still clearly remembers the drama around the annexation of Tekoa D. Settlers from Tekoa had repeatedly tried to open a road to the hilltop, eventually hiring a private contractor to level the land for the caravans to move in. Residents of Tuqu' had responded by staying for several weeks on their lands to prevent the contractor from starting the construction work. 'One moming',

\footnotetext{
${ }^{2}$ Although water use restrictions are based on the shares made during the O slo Accords, O slo II (1995) promised Israeli withdrawal from the West Bank before the 1997 and the end of occupation in 1999 after the final agreement on refugees, water, settlements, and the status of Jerusalem (Fisk, 2007:420-440; Selby, 2003: 30-31). O bviously, these agreements have not been implemented, nor the water quotes updated to meet contemporary demands.
} 
the former official recalls, 'Israeli military put up a strict and tough curfew for the entire town'. It soon came out that two settler youths were found dead in a nearby cave. D ozens of Palestinians from Tuqu' were arrested and the village remained closed for three consecutive days. 'On the fourth day', the ex-official says, 'they released the people and stopped the curfew, and we discovered that settlers had opened up a road and levelled the area [of Tekoa D ] - even the caravans were already there'.

With the help of the municipality, Palestinian landowners raised a court case against the settlers in the Israeli High Court of Justice. The claimants had all the required property documents, which the High Court of Justice also recognized as legitimate without further ado, thus ordering the settlers to evacuate the outpost structures immediately on the grounds that they were built on the lands legally owned by the Palestinians claimants. Since 2001, however, the outpost has been given an official representative, gained its share of settlement budget, and connected to settlement's electricity and water infrastructure, while its inhabitants enjoy the same rights as the other settlers (see ARIJ, 2015: 10-11; Lazaroff, 2015). 'The court may say something, but the govemment does the other', my interviewee says in frustration, referring to the fact that Israeli military never evacuated the outpost, but rather denied Palestinian landowners access to their lands because of 'security reasons'. Recently, Tekoa D has again become topical as a site of collective punishment. As compensation for the demolished Tekoa E - new outpost established in 2014 after the killing of three settler teenagers in Hebron, whose deaths served as a pretext for igniting the $2014 \mathrm{G}$ aza War (see Blumenthal, 2016; Joronen, 2016a) - settlers were allowed to start filing master plans for Tekoa D (Stahl, 2015: 27). Again, Tekoa D is gaining authorization from the deaths of settler youths, whose killings have no proven connection whatsoever to the Palestinian landowners, or anyone from Tuqu'.

A similar set of events unfolded during another fieldwork I conducted in 2015. A family, owning a farm surrounded by the settlements of Gush Etzion block near the West Bank village of Nahalin, had already started their legal and administrative struggle back in 1991, when the Israeli Military Court had declared their farmland as 'state land'. Israeli authorities had come to this verdict by leaning on the old Ottoman era Land Code (article 78), which Israel has for several decades used to justify land confiscation in the occupied West Bank. Before the Israeli occupation, especially under the Jordan rule, this Ottoman Land Code had ensured farmers' ownership of unregistered land after 10 sequential years of cultivation (despite possible cessation of cultivation or lack of original permits). Israel, however, saw an opposing interpretation, whereby any break in cultivation gives the state a right to confiscate unregistered land (Shalev, 2012: 28, 40-42). With this pretext, Israeli authorities were able to take advantage of the generational change in the farm, during which the farm activities could not be properly taken care of. In this particular case, the family did possess the original registration documents; yet, several efforts of the family to claim legal ownership to their farmlands were turned down. Finally, the family took the case to the Israeli High Court of Justice, which after several expansions and requirements for extra documentation of the original registration finally made a verdict in 2005 in favor of the Palestinian family. The land struggle, however, had already taken 14 years, during which time the family had not been allowed to build any infrastructure on their lands, nor repair the existing farm premises. This, including a roadblock set up by the military to the only road leading to the farm, had severely hampered the agricultural activity and the livelihood of the farm. Even today, the farm activities are managed without running water, electricity and proper road connection, while at the same time the farm has been continuously threatened by settler attacks, including outpost establishment and land appropriations held under the protection of the Israeli military. The family has only been able to eschew these precarious conditions with clever everyday practices, including the use of solar panels, arrangement of collective activities, or the construction of premises in caves and underground.

Given the fact that the Israeli High Court of Justice did recognize the family as the legal owner of the farmlands, it is curious that its verdict in 2005 brought hardly any relief to the precarities listed above. In fact, the legal recognition of the land ownership only ensured that the land registration process could begin. To start the process, a land survey of the farmlands was required, consisting of several phases from signature-collection to exact mapping - altogether a slow and expensive process 
that in most cases ends up in the rejection of Palestinian applications, as they hardly ever meet the conditions imposed by the ICA. In this particular case, the permit process is still ongoing and has already taken 12 years due to slow processing, additional documentation requirements, and several rejections. Again, no permits for the building of proper infrastructure for the farm have been granted for the family, while simultaneously several demolition orders have been warranted to the "unregistered" farm, most recently in D ecember 2015. These demolition orders have not only been directed to the new means through which the family has been able to resist the precarious living conditions (e.g. to rooftops under solar panels, or premises built underground), but also to the premises built before the 26-year-long land struggle.

What makes the non-violent resistance of the family even more frustrating is similar to the situation we already saw in Tuqu'. Even in a case of successful land registration, concession for building permits is not guaranteed. In fact, the denial of Palestinian building permits, construction and the development of infrastructure has been Israel's long-term policy in Area C. According to OCHA ('United Nation's Office for the Coordination of Humanitarian Affairs in occupied Palestinian territory'), $70 \%$ of Area C in the West Bank is off-limits for Palestinian use and development, while in $29 \%$, Palestinian construction is heavily limited, with only $1 \%$ of the land being allocated for Palestinian development (OCHA, 2014b, 2015).

As the allocation of land in Area $\mathrm{C}$ indicates, the practices discussed above are not restricted to a single farm in Nahalin, or one road in Tuqu'. Rather, they are a steady feature of controlling and colonizing West Bank in tandem with, but also despite, the legal decisions seemingly characteristic for the liberal-democratic states. These mechanisms of appropriation do not seem to base their power on the rule of the exceptions, which G ordon (2008:21), among others (see Lloyd, 2012; O phir, et al. 2009), sees as central to contemporary Israeli controlling practices, particularly after the Second Intifada (Palestinian uprising 2000 2005). Instead, they ground their power on the combination of slow and offsetting regulatory, legal and administrative practices, which retain (and thus produce) the precarious spaces of everyday Palestinian life. Not only building permit restrictions, but also slow back-and-forth legal, bureaucratic and security procedures produce administrative performances and theaters of justice, which keep the Palestinian population waiting for the actualizations of their rights in precarious limbos of government. These techniques - sometimes overlapping, sometimes overcoming and negating the acts of other governing bodies - do not abandon Palestinian lives to the zones of exception (Agamben, 1998: 28-29, 64; 1999:155), but instead recognize the Palestinian right to have rights, simultaneously ensuring that the vulnerable conditions remain prolonged. As the road and well construction projects show, decisions on permit applications can be delayed or repealed without specific reason being given. While these events are yet to be dealt with in the Israeli High Court of Justice, court decisions do not guarantee reduction of precarities, nor implementation of Palestinian rights, as the events in Tekoa D and the farm in Nahalin show. Accordingly, there is a tendency in Israel's occupation for the Supreme Court orders to become constantly overturned by security exceptions (as the outpost establishment in Tuqu' underlines) or delayed by the slow and stalling administrative proceedings (as the farm near Nahalin shows). Together with delays, slowness and postponements, exceptions are hence an integral part of the theatric scenes of justice that maintain precarities by denying the implementation of Palestinian rights. Yet, it is precarity, as the next part shows, which operates as a galvanizing point here: in the 'spaces of waiting' precarity is prolonged, induced and strengthened by the overlapping and overturning ways of state-produced recognitions.

\section{Politics of waiting: Precarity, recognition and performativity, revised}

The seemingly endless piling up of successive and often counteracting legal, administrative and policing processes, it can be argued, is in itself a modality of government grounded on state performances, where the legal and political right to claim rights is recognized, but the enforcement of rights delayed, kept pending or prevented. As a logic of government, such delays contain a number of techniques, including requirements for extra documentation, additional high cost procedures, 
building restrictions, security limitations or demolitions during pending applications, which all maintain and prolong vulnerabilities among the ones governed, while simultaneously ensuring their legal rights are ceremoniously recognized and kept alive. Such performances cannot be considered as mere corollaries of bureaucratic slowness (A uyero 2012): not only have some reactions of Israeli state apparatuses been remarkably quick (when strategically wise), but also the postponement itself is part of a broader trend evolving since the 0 slo Agreements. As G hazi-Walid Falah (2005: 301) has shown, by deciding not to decide on the thomiest issues - on the status of East Jerusalem, the fate of Palestinian refugees and the settlements in the West Bank - these postponements of O slo have eventually turned into 'a strategy of stalling', coupled with a 'colonizing race for acquiring more and more territory to create irreversible geographical reality of expanded settlements' (see also Amir, 2016). Although I agree with Falah, my aim here is not to look at the implementation of settler colonialism or the strategy of stalling against the geopolitical backdrop. Instead, I will look at the spaces of waiting at the level of everyday life, focusing on three elements - precarity, recognition and performativity - and the way they come together as a means to govern and colonize.

Certainly, several established vignettes already exist within the literature dealing with the manifold aspects of waiting (see Creswell, 2012). Bissell (2007), for instance, has looked at the ways in which waiting is embodied to (im)mobility and (in)activity, while the central role 'waiting' plays in the experiences of refugees and asylum seekers, particularly as they grow from the stalled politics of detention and protracted refugee situations, has been widely discussed (e.g. D arling, 2014; Hyndman \& G iles, 2015; Pascucci, 2015). Another body of works has made the role of waiting in governing its centre of foci, concentrating on the 'bureaucratic waiting' on the one hand, and the 'durative waiting' in the disquieting limbos of liberal managerialism (where everything is under constant and confusing reforms) on the other (e.g. Jeffrey, 2010; Povinelli, 2011). Though affording valuable insight on how waiting can manifest itself in government, constant reforming is unlikely to be the crux here, albeit policy changes and hardening administrative requirements do occur, especially during the processes that last for several decades. Surely, the continuous transition from one slow process to another can itself function as a technique of government, which subjects the ones governed to limbos where no significant improvement takes place. As Auyero $(2012: 9,19)$ aptly holds in his study of Argentinian shanty residents, waiting is not just something bureaucracy breaths and the poor internalize (for instance, when patiently complying with arbitrary and unjust requirements just to avoid making troubles); waiting also creates the subordinate by producing and maintaining uncertainly among the precarious. Transitions, reforms and bureaucratic slowness may thus play a significant role in constituting 'spaces of waiting', but only as singular techniques of implementing its logic of government. That is, the logic of granting Palestinians a right to claim their rights without fulfilling the recognized entitlements or removing the precarities of the occupied.

Since the essays published under the title Precarious L ife (2005), Judith Butler has elaborated the notion of precarity specifically in relation to social and political ontologies producing, distributing and framing the real-life precarities in manifold ways (see Kearns, 2013). As fragile, perishable and precarious as life always is, its precarity is never evenly distributed, produced or maintained among the living, but prone to political and social framings of different kinds. These frames anchor their power to the practices that distribute precarity among bodies, spaces and populations, in some instances by separating the life worth of protection from those considered to pose a mere threat to secured life, while in other cases protecting the 'valuable' and 'livable' life with less precarious administrative, legal and political covers. However, as Butler (2010) explicates in Frames of War, precarity is not only constituted in close relation to social and political conditions of grievable (and so livable) life, but also manifests a general condition of all living: their inherent precariousness, frailty and finitude. Here Butler expands the sphere of precarity significantly beyond the analyses limiting the term to a certain, now in many ways globalized modes of production first emerging in the post Second World War Europe (e.g. Standing, 2011). Butler's discussion, however, does not exclude such analyses of precarization (See Lorey 2015), nor simply turns historically and spatially specific concept 
to a universal one (See Oliver 2015). ${ }^{3}$ Instead, precarity denotes an ontological differentiation of life, where the general precariousness, frailty and finitude of living (whether human or not) emerges through the politically and socially induced frames of precarity. In spite of the historical and spatial specificity in framing precarity, precariousness is never limited to instances of its production, whether these instances consist of Eurocentric modes of production or new global class structures produced by neoliberal policies (Standing, 2011: 7-12). Instead, the frames of precarity constitute 'political ontologies', which use the precariousness of life as an instrument of government in ways that are spatially, historically and socially manifold (Joronen 2016b: 96).

Considering the general character of precariousness, it is no wonder Butler has recently turned her focus from the frames of vulnerability (i.e. of governing) to the acts of the vulnerable (i.e. the governed), particularly to the role 'performative politics' plays in 'claims of the precarious' for recognition and rights (Butler, 2015: 33-34). In addition to the ambiguity between 'life as precarious' and the 'framing/ production of precarity', the recent work of Butler underlines another ambiguity, located between the 'frames of government' (that make certain bodies more precarious than the others), and the 'resisting bodies' (that aim to alleviate the precarities imposed upon them) (See Butler, 2016; Hammami, 2016). For those in a precarious position, however, the performative power of (assembling) bodies may be the only way to claim rights or question the discriminatory power relations. Although to some extent the operations of the state also need to be performed, those in power always have options to govern by other means than by performing (Butler, 2015: 8-10; Butler and Athanasiou, 2013: 99-102).

With regard to events in Tuqu' and Nahalin, this dynamic of performing seems particularly complicated. In them state procedures are not ritualized ways of everyday confirmation that the state apparatuses need to maintain their power effectively (Hansen and Stepputat, 2005:7). Rather than implementing the rights, which the settler colonial state itself recognizes Palestinians to have, such state performances create spaces of waiting in the midst of processes they keep operative. These performances thus represent themselves as agents of a right-recognizing state, which on the one hand confirm the Palestinian right to have rights, but on the other do not allow these rights to become actualized in a manner that would alleviate the precarities induced by the occupation. Such acts are theatrical, not in a sense of making the systematic production of settler colonial rule somehow 'unreal' or 'ineffective', but in a sense of masking the settler colonial project into just administrative and juridical processes recognizing the Palestinian right to claim rights. As Povinelli (2011:79) writes in another context, such bracketed recognition' is not a counterforce of camouflaging, but 'one mode of apprehending the other [... ] alongside espionage and camouflage'. With theatricality, I thus refer solely and exclusively to this performance of accepting, which masks the settler colonial occupation and its ways of maintaining violence, oppression and precarity by liberal means often silent and far from hostile in their first impression. Theatricality hence need to be understood in relation to settler colonial recognition and production of vulnerabilities - as a way of recognizing without an implementation of rights; as a way of active governing without a change in the precarious conditions among the ones governed.

O ne cannot assume a mere recognition of rights thus guarantees political indiscrimination and liveable lives. As several authors (i.e. Daigle, 2016; O liver, 2015; Povinelli 2011) have also acknowledged, recognition may consist of performative functions that ensure precarious conditions abide among the ones recognized. It is precisely for this reason one should separate reognition from the conditions of recognisability. While recognition itself refers to a particular practice or act of recognizing certain groups, bodies and populations (i.e. to inclusion and exclusion), the conditions of recognisability operate at the level of ontology, by framing the ways of recognition, in this case

\footnotetext{
${ }^{3}$ Strictly speaking, vulnerability, as it grows from the fundamental frailty and finitude of life, does not pose a metaphysical statement (about what life is). It rather acknowledges life's perishability - of what life may lose, including itself (i.e. that life is no more), hence denoting a lack and absence rather than a substance (Joronen \& Häkli, 2016; Rose, 2014; cf. Povinelli, 2011: 106-108; O liver, 2015).
} 
Palestinians living on the lands into which Israel aims to expand its settlements. A mere focus on practices of recognition hence remains blind to those general conditions, norms, conventions, categories and frames of recognisability that make possible the acts of recognition (Butler, 2010:4-5; ; Povinelli, 2011: 77-78).

It is hardly a surprise in a context of violent military occupation that recognisability contains border conditions strong enough to prevent alleviation of Palestinian precarity, not only culturally (Harker, 2012) but also juridico-politically (Joronen 2016b). In other words, recognition is not merely a cultural category of exclusion or inclusion, but a juridico-political demarcation of distinction, which structures theatrical performances conducted by different state apparatuses. These apparatuses thus enact and perform certain political distinctions without necessarily naming them as such. This silent demarcation manifests itself, for instance, in the vast difference in the ways in which state apparatuses treat Palestinian and settler populations with regards to law, administration, sentencing, arrests, interrogations etc. (see Falah, 2008; Joronen, 2016b; Khalili, 2013; Smith, 2013). It is not only the assemblages of subsumed bodies then, as Butler (2015: 83) writes, which may exercise 'a right that is no right' (i.e. to perform a right that they lack); also state apparatuses do so as means to govern (i.e. by recognizing and performing rights without implementing them).

To be sure, Butler does refer to a 'theatrical self-constitution' of state apparatuses, including the 'performative forms of power' and the ways of 'partial recognition' they may entail (Butler, 2015: 6, 85), while also arguing that recognition and precariousness do not presume one another, as precarity is not necessarily addressed in recognition, nor recognition the only (or the best) way to register or alleviate precarities (Butler, 2010:13). As Oliver (2015: 479) adds, it is not only the 'vulnerability of the others' that is exploited 'in the situations of oppression, torture and domination', but also the 'recognition of vulnerability' can itself 'enable most brutal violence'. Indeed, it is not the need to alleviate the precarity of the Palestinian population that is recognized in the theatres of governance, but the general right to daim rights. The settler colonial apparatuses legitimize their operations precisely by recognizing the occupied bodies, at the same time affirming that the precarious spaces of occupation remain. Such a way of recognizing does not lead to a reconstitution of precarity, but rather grows from the structural conditions of recognisability, which lean on the settler colonial aim to control and inhabit the 'maximum amount of land with the minimum presence of the natives' (Salamanca et al., 2012:1-2). Under the settler colonial conditions of recognisability, recognition of the right to have rights turns to a theatrical performance of rights, which does not reconstitute, but reinforces precarities of the occupation through the spaces of waiting it so establishes.

\section{Theaters of recognition: performing rights, maintaining precarities}

As the discussion above shows, the 'spaces of waiting' consist of theatrical performances through which the settler colonial state apparatuses maintain precarities among the occupied population. The crux here, however, is not the way of acting 'from' or 'against' the precarity (Butler, 2015: 58), but the way in which the theatrical nature of state performance affects the relationship between recognition and precarity on the one hand, and the way in which 'acting from' and 'acting against' precarity are both captured to support the theatres of recognition on the other. As the first point underlines, instead of recognizing the need to alleviate precarities, these state performances maintain, induce, improve, and prolong precarities among Palestinians, particularly among those dwelling in locations Israel sees as strategically important for the expansion of its settler colonial enterprise. Such performances are theatrical - slow spectacles or never-ending plays rather than implementations of rights. Instead of affording venues for making and performing new worlds and identities ( $\mathrm{G}$ ibsonGraham, 2008), these theatric performances keep legal, administrative, and military apparatuses operative in a manner seemingly peculiar to liberal-democratic states (Yiftachel, 1998). Not only are the discriminatory structures of settler colonial rule rendered invisible by the Israeli security concerns, as Shalhoub-Kevorkian has convincingly shown (2015), but also by the continuous tardiness and stagnation in often counteracting court proceedings and administrative decision making processes, 
which do so by maintaining precarity undemeath the recognition they simultaneously claim to perform.

In addition to myriad ways of producing precarity through the liberal-democratic liturgies of legality, these theaters also capture the non-violent Palestinian resistance and the shared sense of injustice inside their functions of control. As the road and well construction projects in Tuqu' highlighted, Palestinian landowners and municipalities are well aware of the fact that engaging in court processes is more likely to lead to extended delays than justice and compensation. The reasons for operating within the legal frameworks nonetheless, are various: the negligible chance that complaints and petitions are accepted, the urge not to give more excuses for inducing further injustices, or the culturally shared persistence and 'steadfastness' of not giving up for the injustices of the occupation (See Joronen, 2017; Leshem, 2015). Yet, when drawn into processes of theatric recognition, forms of resistance and moods of injustice transform into a waiting rather than implementation of rights. These state performances can hence ignite, direct, or even vitalize Palestinian agency through recognition, yet they do so without improving the living conditions of the occupied. Such activation aims, somewhat paradoxically, to maintain the precarity of life by directing the energies that resist state induced precarity to an activity that maintains the precarious state of affairs.

As Mitch Rose (2014: 215-218) describes in his paper on 'negative governance', modes of government that are directed to use precarities of life also pose a challenge for both Foucauldian and Agambenian understandings of biopolitics and government(ality) (see Coleman and Grove, 2009; Legg, 2016). With 'negative governance', Rose refers to a form of state governance he faced during the work carried out in the village of $\mathrm{N}$ azlat al-Samman in Egypt. By 'exposing villagers to the precariousness of life itself', Rose writes, the state did not 'attempt to control life but use life (in its inherent frailty) as a strategic asset' (Rose, 2014: 214). Such governance cannot be considered as a form of Foucauldian biopolitics, as it does not aim to protect life from the vulnerabilities. The basic function of biopolitics, as it operates to "improve life, to prolong its duration, to improve its chances, to avoid accidents, and to compensate for failings" (Foucault, 2003:253), is to mobilize life-improving techniques and thus to positively direct (often with a 'hopeful ethos') the conduct of a population to a desired direction (Rose and Abi-Rached, 2013; Millei and Joronen, 2016). Negative governance does the opposite: uses the precariousness of life as a means to govern. In fact, it is precisely for this reason that negative governance does not parallel to Agamben's thanatopolitical vision of biopolitics either: instead of sovereign state, in negative governance it is the inherent precariousness of living, which operates as an agent of governing (Rose, 2014). For Rose the Egyptian village was neither governed through the exceptionalities based on state's 'inclusive exclusion' of bare life from the political rights (Agamben, 2005: 23-24) nor regulated through the positive ethos of biopolitics, but rather controlled through the vulnerabilities maintained by the complete (but strategic) withdrawal of the state.

Even though Rose's discussion of 'negative governance' helps in further understanding how the production of precarity operates as a way of governing, the modality of government I have tried to capture with the discussion around theatric performance, recognition and precarity contains several characteristics which separate spaces of waiting from all the modes of government discussed above. Firstly, in the cases I described earlier, theaters of state apparatuses are not grounded on the withdrawal of the state apparatuses, nor a strategic refusal to govern, but on the gap between the recognition and the implementation of rights. It is precisely the gap that I call the space of precarious waiting. In other words, Palestinian bodies were not strategically abandoned to the authority of the life itself (i.e. to the existential precariousness of all living); they were rather caught into 'cycles of circulating and waiting' (Secor, 2007: 39), which offered recognition, but without alleviation of precarity. Instead of letting the inherent vulnerability, finitude, frailty, and unpredictability of life rule, these existential conditions were actively used in the theaters of recognition, not only to govem and manage Palestinian life, but also to support the aims of the settler colonial regime. 
Secondly, although the waiting cannot be grounded on the biopolitical functions of the state, particularly as the waiting does not remove but maintains and increases vulnerabilities, it nonetheless does require that the Palestinian right to have rights is recognized. Such recognition may engender and foster the agency of the precarious, as the events in Tuqu' and Nahalin show, but merely to maintain the theaters of recognition. It is for the same reason such waiting cannot operate as a form of thanatopolitical abandonment (cf. Hammami, 2016: 169) - the Palestinian right to rights is not abandoned, but recognized in the theaters of state apparatuses. In this regard 'theaters of recognition' could be seen as a part of the 'liberal lawfare', which invocates, as Khalili writes (2013:4), law and legality 'as structuring the conduct of war' waged to maintain, for instance, 'the regimes of occupation', 'counterinsurgencies' or 'War on Terror'. In theatres of recognition, however, legality is not a structuring condition but merely enacted - left without actualization, and so to support the discriminatory structures of the settler colonial rule. Law is an 'instrument of legitimation' as Khalili holds (contra Schmitt and Agamben), but not due to its malleable power to justify and legalize brutalities of liberal wars, but rather due to its ability to hide the theatric nature of settler colonial recognition. In these theaters, legality is not stretched to its interpretative limits, nor is law given a status to ensure administrative compliance and excessive use of military force (Khalili, 2013: 67). What is at stake in the spaces of waiting is a practice of government delaying, stalling and denying the implementation of (recognized) rights. As a part of the settler colonial rule, law is an instrument that legitimizes settler colonial privileges by maintaining what these privileges fundamentally lean on: the precarity of the occupied.

Thirdly, in such theaters we can find both, repressive and productive forms of governance simultaneously at play. Unlike studies that suggest the separation of biopolitical governmentality from the repressive practices of the state (Parsons and Salter, 2008), or the 'productive bio-power' from the 'deductive sovereign power' (Ojakangas, 2005), these theaters show how a recognition of rights and agency can simultaneously repress and subjugate the ones recognized. As Athena Athanasiou (Butler and A thanasiou, 2013: 30-31) also recalls, there is a need to 'critically engage the integral coimplication and coevalness' of the subjugating functions of power and the productivity in capacitating modes of living (see also Joronen, 2016a; Mbembe, 2003; Prozorov, 2013). This can be achieved by looking at concurrent and unexpected configurations of power in their overlapping, often complex and conflicting ways of operating in relation to one another. While offensive measures for eliminating Palestine from the landscapes (Fields, 2012), or Palestinians from humanity (Shalhoub-Kevorkian, 2014), have been (and still are) used to maintain the occupation, in other instances settler colonial aims are implemented through less belligerent legal and administrative processes that separate the political recognition from the reduction of politically induced precarities.

\section{Conclusion}

As I have shown in the previous pages, spaces of waiting operate as a way of government that actively maintains the precarious situation of the colonized. While in the case of precarity the governmental aspect is more or less evident, with regard to performativity and recognition, more discussion is still required for teasing out their manifold and complex uses in different configurations of power. In this paper, I have suggested that one way to do so is by looking at the theatrical scenes of state apparatuses, which recognize the Palestinian right to have rights, but simultaneously capture Palestinian non-violent resistance and sense of injustice into performances that do not change the precarious conditions that catalyzed Palestinian claims for rights in the first place. Such slow-motion government can be applied in different stages and processes of government - in administrative permit-processes, as the road and well construction projects in Tuqu' showed, but also when the implementation of court decisions are prolonged with constant friction in administrative practices, or put on hold due to the 'security reasons'. Moreover, these precarities may be prolonged through myriad techniques, including slow processing, endless requirements of additional documentation, exacting permit requirements, demolition orders placed during the pending processes, endless waiting of building permits, protection of unauthorized outposts, impunity regarding the settler vigilantism, 
or the counteracting decisions of different state apparatuses. The right to claim rights, security and proper governance may hence be recognized, but under the settler colonial conditions of recognizability, which subjugate the Palestinian population under precarious living conditions. As Coulthard (2007) and Daigle (2016) have also shown in the context of indigenous rights in Canada, when 'politics of recognition' is implemented by the colonial state, it easily ends up reproducing the existing configurations in colonial power relations.

Yet, production of precarity does not merely subsume Palestinians of occupied territories into passive targets of power, but also forces and pushes them to act against the induced precarity. It is a unique counter-strategy to vitalize the forces of resistance to serve the theaters of state governance, particularly as such directing maintains the precarity of colonized lives by turning resistance of precarity into an activity, which maintains the precarious situation itself. Such circularity is not a 'Foucauldian circle' (Cadman, 2010: 541; Hamann, 2009; Rose, 2014: 216), where state apparatuses simultaneously respond to and reinforce the problem, which they on the one hand create, but on the other hand make a central concern of the state. It is rather a vicious circle, which makes justice the state's concern without changing the precarious situation of the ones governed. Such a circle should not be seen as a mere mistreatment of 'authentic' liberalism, but as a form of settler colonial violence with 'bloody hands and honeyed tongues' (K halili, 2013: 4). It is an attempt and omission at the same time - an instrument of legitimation that simultaneously responds and maintains the problem, not by reinforcing it, but by strategically failing to remove the underlying precarities and structural discrimination. Even though in this sense juridical, administrative and political recognition of the Palestinian right to have rights may encourage and catalyze Palestinian agency, eventually the process benefits the aims of the settler colonial regime. These theaters may thus promote administrative, legal and security procedures peculiar to liberal-democratic states, but simultaneously delay them in order to make time and space for the settlement expansion, often to a point where outposts are persistent enough to become combined with the existing settlement infrastructure, as the discussion of Tekoa D exemplified.

By investing the above-discussed forms of recognition and management, the state of Israel is able to vitalize, polish and legitimize its settlement enterprise, while at the same time depleting the livelihood of Palestinian spaces, even to a point of making them 'legally' disposable. In this, even though the discussions put forward by Rose and Butler help to show how the origin of government resides on the inherent vulnerability and precariousness of life, attention should be paid to those ways of governing through which precarity becomes induced, framed and produced. Rather than focusing on 'lawlessness' of the occupation, or the obvious forms of power and politics (e.g. Gordon, 2008; Parsons and Salter, 2008), more attention should be hence paid on the unorthodox configurations of power constituting manifold precarities, not only in close relation to the sites of everyday life, but by using law and administrative means as less aggressive and hostile tools for hiding the settler colonial violence of the occupation. 


\section{References}

Agamben G (1998) H omo Sacr: Sovereign power and bare life. Stanford: Stanford University Press.

Agamben G (1999) Potentialities: Collected essays in philosophy. Stanford: Stanford University Press.

Agamben $G$ (2005) State of E x ception. Chicago: The University of Chicago Press.

Amir M (2016) Revisiting politicide: state annihilation in Israel/ Palestine. T erritory, P olitics, G overnanœ (online), doi: 10.1080/ 21622671.2016.1231630

ARIJ (2010) Tuqu' Village Profile. Palestinian L ocalities Study. Jerusalem: Applied Research Institute Jerusalem.

ARIJ (2015) The settlement of T ek oa. Jerusalem: Applied Research Institute - Jerusalem.

Auyero J (2012) Patients of the State. The politics of waiting in A rgentina. D urham \& London: Duke University Press

Bissell D (2007) Animating Suspension: Waiting for Mobilities. M obilities 2(2), 277-298.

Blaser M (2014) Ontology and indigeneity: On the political ontology of heterogenous assemblages. Cultural G eographies 21: 49-58.

Blumenthal M (2015) The 51 day war. R uin and resistance in $\mathrm{G}$ aza. London: Verso.

B'tselem (2014) The West Bank. Settlements and the Separation Barrier, November 2014. Available at: http:/ / www.btselem.org/ download/201411_btselem_map_of_wb_eng.pdf (accessed 10 November 2016)

Butler J (2005) Precarious life. The powers of mourning and violence. London: Verso.

Butler J (2010) Frames of war. W hen is life grievable? London: Verso

Butler J (2015) N otes toward a performative theory of assembly. Harvard: Harvard University Press.

Butler J (2016) Rethinking vulneralibility and resistance. In: Butler J, Gambetti Z and Sabsay L (eds) $\mathrm{V}$ ulnerability in resistanœ. D urham: D uke University Press, pp. 12-27.

Butler J and Athanasiou A (2013) D ispossession: The performative in the political. Cambridge: Polity Press.

Cadman L (2010) How (not) to be governed: Foucault, critique, and the political. E nvironment and Planning D : Society and Space 28: 539-556.

Coleman M and Grove K (2009) Biopolitics, biopower, and the return of sovereignty. E nvironment and Planning D : Society and Space 27: 489-507.

Coulthard GS (2007) Subjects of empire: Indigenous peoples and the 'politics of recognition' in Canada. C ontemporary Political Theory 6: 437-460.

Cresswell T (2012) Mobilities II: Still. Progress in H uman G eography 36(5):645-653

D aigle M (2016) Awawanenitakik: The spatial politics of recognition and relational geographies of Indigenous self-determination. The C anadian $\mathrm{G}$ eographer 60: 259-269.

Darling J (2014) Another letter from the Home Office: reading the material politics of asylum E nvironment and Planning D : Society and Space 32: 484-500.

EWASH (2016) E W A SH concerned by water restrictions in the W est Bank resulting from Israeli discriminatory policies. The Emergency, Water, Sanitation and Hygiene Group. Available at: http:/ / www.ewash.org/ sites/ default/ files/ inoptfiles/ 160621\%20-\%20EWASH\%20PR\%20Water\%20Restrictions\%20West\%20Bank\%20Result\%20of\%20Israeli\%20D iscriminatory\% 20Policies.pdf (accessed 30 November 2016)

Falah G-W (2005) Peace, deception and justification for territorial claims: the case of Israel. In: Flint D (ed) The geographies of war and peace. F rom death camps to diplomats. Oxford: O xford University Press, pp. 297-320.

Falah G-W (2008) G eography of ominous intersection with interrogation and torture: reflection on detention in Israel. Third W orld Q uarterly 29: 749-766.

Fields G (2012) 'This is our land': collective violence, property law, and imagining the geography of Palestine. Journal of Cultural G eography 29: 267-91.

Fisk R (2007) The great war for civilisation. The conquest of the Middle E ast. New York: Vintage Books, Random House Inc.

Foucault M (2003) 'Society Must Be D efended'. L ectures at the College de France, 1975-1976. New York: Picador. 
G ibson-G raham JK (2008) D iverse economies: performative practices for 'other worlds'. Progress in $\mathrm{H}$ uman $\mathrm{G}$ eography 32: 613-632.

Gordon N (2008) Israel's 0 caupation. Berkeley: University of California Press.

Griffiths M (2017) Hope in Hebron: The Political Affects of Activism in a Strangled City. A ntipode 49(3): 617-635.

Hamann T (2009) Neoliberalism, governmentality, and ethics. Foucault Studies 6: 37-59.

Hammami R (2016) Precarious politics: the activism of 'bodies that count' (aligning with those that don't) in Palestine's colonial frontier. In: Butler J, Gambetti Z and Sabsay L (eds) V ulnerability in Resistanoe. D urham: D uke University Press, pp. 167-190.

Hansen TB and Stepputat F (2005) Introduction. In: Hansen TB and Stepputat F (eds) Sovereign B odies. Citizens, Migrants, and States in the Postoolonial W orld, Princeton: Princeton University Press, pp. 1-38.

Harker C (2012) Precariousness, precarity, and family: notes from Palestine. E nvironment and Planning A 44: 849-865.

Hyndman J and Giles W (2011) Waiting for what? The feminization of asylum in protracted situations. G ender, Place \& C ulture 18(3):361-379.

Jeffrey C (2008) Waiting. E nvironment and Planning D : Society and Space 26: 954-958.

Jeffrey C (2010) Timepass: Y outh, class, and time among unemployed young men in India. A merican E thnologist 37(3): 465-481.

Joronen M and Häkli J (2016) Politicizing Ontology. Progress in H uman G eography, (online): doi: $10.1177 / 0309132516652953$

Joronen M (2017) 'Refusing to be a victim, refusing to be an enemy'. Form-of-life as resistance in the Palestinian struggle against settler colonialism. Political G eography 56: 91-100.

Joronen M (2016a) 'D eath Comes Knocking on the Roof': Thanatopolitics of Ethical Killing during O peration Protective Edge in G aza. A ntipode 48(2): 336-354.

Joronen M (2016b) Politics of Precarious Childhood. Ill Treatment of Palestinian Children under the Israeli Military O rder. G eopolitics 21(1): 92-114.

Khalili L (2013) Time in the shadows. Confinement in counterinsurgencies. Stanford: Stanford University Press.

Kearns G (2013) The Butler affair and the geopolitics of identity. E nvironment and Planning D: Society and Space 31: 191- 207.

Kotef $\mathrm{H}$ (2015) M ovement and the 0 rdering of Fredom. On L iberal G overnance of Mobility. D urham: Duke University Press.

Lazaroff T (2015) I don't believe salvation will come from this government. The Jerusalem Post, 14 May 2015.

Legg S (2016) Subject to truth: Before and after governmentality in Foucault's 1970s. E nvironment and Planning D : Society and Space 34(5): 858-876.

Levinson C (2015). 2.026 Settlement Houses Build on Private Palestinian Land, Right-wing Study Finds. H aaretz, 12 May 2016.

Leshem N (2015) 'O ver our dead bodies'. Placing necropolitical activism. Political G eography 45: 34-44.

Lloyd D (2012) Colonialism and the State of Exception: The Example of Palestine/ Israel. Settler Colonial Studies 2: 59-80.

Lorey I (2015) State of Insecurity. London: Verso.

Mbembe A (2003) Necropolitics. Public C ulture 15: 11-40.

Millei Z and Joronen M (2016) The (bio)politicization of neuroscience in Australian early years policies: fostering brain-resources as human capital. Journal of E ducation Policy 31(4): 389-404.

Ministry of Planning and Administrative Development (2015) First Monitoring Report 2014 of the National Development Plan (NDP) 2014-16. State of Palestine: Monitoring and Evaluation Directorate.

OCHA (2014a) A rea C vulnerability profile. East Jerusalem: United Nations Office for the Coordination of Humanitarian Affairs in Occupied Palestinian Territory.

OCHA (2014b) A rea C of the W est Bank: Key H umanitarian C oncerns, U pdate A ugust 2014. East Jerusalem: Office for the Coordination of Humanitarian Affairs occupied Palestinian territory. 
OCHA (2015) Under Threat. D emolition orders in A rea C of the West Bank. Available at: https:/ / www.ochaopt.org/ demolitionos/ demolition_orders_in_area_c_of_the_west_bank_en.p df (accessed 30 November 2016)

Ojakangas M (2005) Impossible D ialogue on Bio-power: Agamben and Foucault. Foucault Studies 2: 5-28.

O liver K (2015) Witnessing, Recognition, and Response Ethics. Philosophy \& R hetoric 48(4): 473-493.

Ophir A, Givoni M and Hanafi S (eds) (2009) Power of inclusive ex clusion. A natomy of Israeli rule in the 0 ccupied Palestinian Territories. New Y ork: Zone Books.

Parsons N and Salter MB (2008) Israeli Biopolitics: Closure, Territorialisation and Governmentality in the Occupied Palestinian Territories. G eopolitics 13: 701-723.

Pascucci E (2015) D iaspora, Immobility, and the Everyday Politics of Waiting: Young Iraqi Refugees in Contemporary Cairo. In: Gorman A and Kasbarian S (eds) D iasporas of the Modern Middle E ast. Edinburgh: Edinburgh University Press, pp. 338-369.

Peteet J (2008) Stealing Time. Middle E ast Report 38: Available at: www.merip.org/ mer/mer248 (accessed 1 D ecember 2016)

POICA (2015) The Israeli occupation authorities ban the opening of an agricultural road in Tuqu'. Available at: http:/ / www.poica.org/ details.php?Article=8491 (accessed 30 N ovember 2016).

Povinelli E (2011) E conomies of A bandonment. D urham \& London: D uke University Press.

Prozorov S (2013) Powers of Life and D eath: Biopolitics beyond Foucault. A lternatives: G lobal, L ocal, Political 38: 191-193

Ram M (2015) Colonial conquests and the politics of normalization: The case of the Golan Heights and Northern Cyprus. Political G eography 47: 21-32.

Ram M (2013) White But Not Quite: Normalizing Colonial Conquests through Spatial Mimicry. A ntipode 46: 736-753.

Rose M (2014) Negative governance: vulnerability, biopolitics and the origins of government. Transactions of the Institute of British $G$ eographers 39: 209-223.

Rose M (2016) A Place for Other Stories: Authorship and Evidence in Experimental Times. $G$ eohumanities 2(1): 132-148.

Rose N and Abi-Rached JM (2013) N euro. Princeton, NJ: Princeton University Press

Salamanca OJ, Q ato M, Rabie K, and Samour S (2012) Past is Present: Settler Colonialism in Palestine. Settler Colonial Studies 2: 1-8.

Secor A (2007) Between longing and despair: state, space and subjectivity in Turkey. E nvironment and Planning D : Society and Spac 25: 33-52.

Selby J (2003) W ater, power and politics in the M iddle E ast. The other Israeli-Palestine conflict. London: I.B. Tauris.

Shalev R (2012) U nder the G uise of L egality. Israel's D eclarations of State L and in the W est Bank. Jerusalem: B'Tselem.

Shalhoub-Kevorkian N (2014) Human suffering in colonial contexts: reflections from Palestine. Settler Colonial Studies 4: 277-290.

Shalhoub-Kevorkian N (2015) Security Theology, Surveillance and the Politics of Fear. Cambridge: Cambridge University Press.

Smith R (2013) 'A D anger to the Region': Subaltern Geopolitics of Palestinians D etained in Israeli Prisons. The A rab W orld G eographer 16: 75-100.

Staeheli L (2008) Political geography: difference, recognition, and the contested terrains of political claims-making. Progress in H uman G eography 32: 561-570.

Stahl Z (2015) U nder the Radar. Israel's silent policy of transforming unauthoriz ed outposts into official settlements. Y esh Din and The Rights Forum.

Standing G (2011) The Precariat. The N ew D angerous Class. London: Bloomsbury.

Sundberg J (2014) D ecolonizing posthumanist geographies. C ultural G eographies 21: 33- 47.

Tawil-Souri H (2011) Q alandia Checkpoint as Space and Nonplace. Space and Culture 14(1): 4-26. 
UAWC (2014) Land, Water and Human Resources Development in Vulnerable Areas of the West Bank. JUT H 0 O R E U-contract, ENPI/ 2014/ 346-576.

UAWC (2016) U A W C organized a field visit for a delegation from the E uropeen U nion, to see 'Juthoor' project's achievements. Union of Agricultural Work Committees. Available at: http:// www.uawcpal.org/ articleen.aspx?ano $=1700$ (accessed 30 November 2016)

van Wichelen S (2015) Scales of grievability: on moving children and the geopolitics of precariousness. Social and C ultural G eography 16: 552-566

Vasudevan A (2014) The autonomous city: Towards a critical geography of occupation. Progress in H uman G eography 39: 316-337.

Weizman E (2007) H ollow land. Israel's architecture of power. London: Verso.

Wick L (2011) The Practice of Waiting under Closure in Palestine. City \& Society 23(1): 24-44.

Y iftachel O (1998) Ethnocracy: the Politics of Judaising Israel/ Palestine. Constellations 6: 364-390.

\section{Acknowledgements}

I would like to thank Mitch Rose and Stephen Legg, the participants of the workshop N ew Perspetives on the $G$ overnment of the $E$ veryday held at the University of Tampere, and the audience of the Social Theory -lecture I gave at the University of Kentucky, for their rich feedback on the earlier drafts of the paper. I am also thankful for the editorial team of the Society and Space and the three reviewers for their supportive critique. The paper is part of the RELATE Centre of Excellence funded by the Academy of Finland (grant 272168).

Mikko Joronen is a research fellow at the Space and Political Agency Research Group (SPARG), University of Tampere. His research focuses on everyday resistance and government in the occupied Palestinian territories; space and political ontology; and geographical theory, Heidegger's thinking in particular. His recent publications deal with thanatopolitical governmentalities of war, power of everyday resistance, topological theory, and the relationship between ontology, space and politics. 